\title{
Human Coronavirus Infections
}

\author{
Steven H. Myint
}

\section{INTRODUCTION AND HISTORY}

The first report of a human coronavirus was in 1965 when Tyrrell and Bynoe (1965) isolated a virus from the nasal washings of a male child. The child had typical symptoms and signs of a common cold and the washing was found to be able to induce common colds in volunteers challenged intranasally. The virus, termed B814 (after the number of the nasal washing), could be cultivated in human embryo tracheal organ tissue but not in cell lines used at that time for growing other known etiologic agents of the common cold. At the same time, Hamre and Procknow (1966) were characterizing five "new" agents isolated from the respiratory tract of medical students with colds. One of these agents, strain 229E, was adapted to grow in WI-38 cells. Subsequently, Almeida and Tyrrell (1967) showed that these isolates were morphologically identical to the viruses of avian bronchitis and mouse hepatitis. McIntosh and colleagues (1967a), working at the National Institutes of Health in Bethesda, then isolated six morphologically related viruses that could not be adapted to cell monolayer culture but would grow in organ cultures. Two of these isolates, $\mathrm{OC}$ (for organ culture) 38 and 43 were then adapted to grow in suckling mice brain. The term "coronavirus," which described the characteristic morphology of these agents, was accepted in 1968 (Tyrrell et al., 1968a).

\section{HUMAN RESPIRATORY CORONAVIRUSES}

There are a number of human respiratory coronaviruses described in the literature, but few have been well characterized (Table I). On the basis of

STEVEN H. MYINT - Department of Microbiology, University of Leicester, Leicester LE1 9HN, England.

The Coronaviridae, edited by Stuart G. Siddell, Plenum Press, New York, 1995. 


\begin{tabular}{lcl}
\multicolumn{2}{c}{$\begin{array}{c}\text { TABLE I. } \\
\text { Human Classification of } \\
\text { Heronaviruses }\end{array}$} \\
\hline Serogroup & Prototype & Virus \\
\hline A & 229E & 229E \\
& & LP \\
& PR \\
& TO \\
& & KI \\
& & PA \\
& & AD \\
& & Linder \\
B & Others \\
& & OC43 \\
& & OC38 \\
Unclassified & & OC44 \\
& & B814 \\
& & 692 \\
& & OC16 \\
& & OC37 \\
& & OC48 \\
& & HO \\
& & GI \\
& & RO \\
& &
\end{tabular}

serological cross-reactivity, however, it is possible to classify most of them (Reed, 1984; Bradburne, 1970; McIntosh et al., 1969). The two main serogroups are 229E-related and OC43-related and it is these prototype viruses that will be discussed in the rest of this chapter. Coronaviruslike particles have been seen in the stools of humans, but, as they have not been characterized, they will not be discussed in this chapter.

\section{EPIDEMIOLOGY}

Most epidemiological surveys of these viruses as agents of respiratory tract illness have been based on serology, using either complement fixation or hemagglutination-inhibition tests for the two prototype viruses $229 \mathrm{E}$ and OC43. As it is clear that serologically unrelated coronaviruses exist, the prevalence of these viruses is likely to be underestimated. Moreover, it is also certain that not all human respiratory coronaviruses have yet been adapted to tissue or organ culture. This conclusion is supported by a study based in London, England, in which coronaviruses were isolated, by tissue or organ culture, from $18.4 \%$ of patients with common colds. However, a further $13 \%$ of the isolates were able to induce colds in inoculated volunteers, although they could not be identified as any of the known "common cold" viruses (Larson et al., 1980).

The most extensive epidemiological survey of OC43 infection has been the study of the community of Tecumseh, Michigan (Monto and Lim, 1974). A 4-year study involved looking for serological evidence of infection with OC43 
in 910 persons in 269 families. A mean of $17.1 \%$ of individuals showed evidence of infection with OC43 in any one year. There was, however, a cycling of the frequency of occurrence: $\mathrm{OC} 43$ infections occurred in most years but there were peaks of infection every 3 years. Over $80 \%$ of infections occurred despite preexisting antibody with infections gradually diminishing with age. The peaks of infection took place in the winter-spring months. A study of $229 \mathrm{E}$ infections in the same community showed a mean annual rate of $7.7 \%$ infected persons (Cavallaro and Monto, 1970). This figure was half of that recorded in a 6-year study of Chicago medical students, in which there was also marked year-to-year variation with peaks of $35 \%$ incidence (Hamre and Beem, 1972). Nearly all 229E infections also occurred in the winter and spring months. The Tecumseh study showed that either 229E or OC43 was dominant in any one year.

Studies of coronaviruses as causes of clinical illness have shown that coronaviruses are second only to rhinoviruses as the causes of the common cold. In the United States and England, 229E and OC43 are responsible for 1 to $30 \%$ of all clinical cases (McIntosh et al., 1970a,b; Isaacs et al., 1983; Wenzel et al., 1974; Kaye et al., 1971; Owen-Hendley et al., 1972; Bradburne et al., 1967), with approximately an equal number of subclinical infections.

\section{DISEASE MANIFESTATIONS}

Human respiratory coronaviruses are now well accepted as causes of upper respiratory tract illness and, in particular, the common cold. The viruses have been isolated from patients with the common cold and they produce common colds when inoculated into volunteers intranasally (Andrewes, 1962). There is a mean incubation period of 3 days (range 2-5 days) followed by an illness that lasts a mean of 6-7 days (range 2-18 days). The classical clinical illness is well known to all of us and consists of general malaise, headache, nasal discharge, sneezing, and a mild sore throat (Tyrrell et al., 1993). Approximately one tenth of patients will also have a fever and one fifth will have a cough. Table II contrasts the clinical features of rhinovirus type 2-induced common colds, those induced by coronavirus $229 \mathrm{E}$, and the illness caused by the influenza A virus (compiled from Lowenstein and Parrino, 1987; McIntosh et al., 1973, 1974). It is not possible on an individual basis to distinguish rhinovirus colds from coronavirus colds. Although earlier studies suggested that there may be differences in the clinical symptomatology with different coronaviruses, this has not been substantiated.

Less well documented are lower respiratory tract infections associated with coronaviruses. A seroepidemiological study, using a complement fixation test, found that coronaviruses were less likely to be found in hospitalized children with lower respiratory tract infection than in controls with nonrespiratory tract disease. From 565 children with lower respiratory tract infection there was evidence of infection with OC38 or OC43 in 3.5\%, compared to $8.2 \%$ of 245 children in the group with nonrespiratory tract disease (McIntosh et al., 1970a,b). In a later study, however, there was serological evidence of either $229 \mathrm{E}$ or OC43 infection in $8.2 \%$ of 417 hospitalized children under 18 
TABLE II. Clinical Features of Rhinovirus, Coronavirus, and Influenza A Respiratory Tract Infection

\begin{tabular}{lccc}
\hline Clinical feature & $\begin{array}{c}\text { Coronavirus 229E } \\
(\%)\end{array}$ & $\begin{array}{c}\text { Rhinovirus 2 } \\
(\%)\end{array}$ & $\begin{array}{c}\text { Influenza A } \\
(\%)\end{array}$ \\
\hline Fever & $9-23$ & $7-16$ & 98 \\
Nasal discharge and/or obstruction & $94-100$ & $64-100$ & $20-30$ \\
Headache & $32-85$ & $28-50$ & 85 \\
General malaise & $46-47$ & $28-43$ & 80 \\
Sneezing & 85 & 50 & 30 \\
Sore throat & $54-68$ & $87-93$ & $50-60$ \\
Cough & $21-31$ & $64-68$ & 90 \\
Hoarseness & 12 & 57 & 10 \\
Myalgia & 9 & 21 & $60-75$ \\
Watery/sore eyes & 29 & 43 & $60-70$ \\
Chills & 18 & 21 & 90 \\
\hline
\end{tabular}

months of age with lower respiratory tract disease (McIntosh et al., 1974). The incidence of coronavirus infection was higher than that of other respiratory viruses, except parainfluenza virus type 3 and respiratory syncytial virus. It is unlikely that there is a direct infection of the lower respiratory tract with coronaviruses and any association is most probably through secondary phenomena. Though these secondary phenomena are yet to be defined, a link between coronavirus infection of the upper respiratory tract and wheezing attacks has been shown in several studies over the last 20 years (Isaacs et al., 1983; McIntosh et al., 1973; S. L. Johnston et al., unpublished data). At particular risk are asthmatic children, in which up to $30 \%$ of acute wheezing episodes may be due to coronavirus infection. Increased airways resistance has been shown to occur in the upper respiratory tract in nonatopic individuals with colds (Bende et al., 1989; Akerlund, 1993) and asthmatic individuals are likely to be at greater risk.

Nonrespiratory tract illnesses have also been associated with coronaviruses and include multiple sclerosis, pancreatitis, thyroiditis, pericarditis, nephropathy, and infectious mononucleosis (Riski and Hovi, 1980; Apostolov and Spasic, 1975; Arnold et al., 1981). The association with multiple sclerosis has been of particular interest since coronaviruslike particles were seen in the postmortem brain of a patient who died with the disease (Tanaka et al., 1976). Subsequently, OC43-related coronaviruses were isolated from the brain material of two multiple sclerosis patients (Burks et al., 1980), although it is likely that these isolates were murine coronaviruses present in the mice used for cultivation (Weiss, 1983; Gerdes et al., 1981; Fleming et al., 1988). Seroepidemiological studies trying to ascertain an association of coronaviruses with multiple sclerosis have been conflicting (Madden et al., 1981; Salmi et al., 1982; Hovanec and Flanagan, 1983; Leinikki et al., 1981). Gene detection has failed to detect OC43 (Sorensen $e t$ al., 1986) but has suggested a neurotropism for 229E (Stewart et al., 1992). It is clear that further research in this area is needed.

The role of coronaviruses in causing diseases outside the respiratory tract has been doubted, in part, because there has been no evidence that the virus can 
spread from the nasal mucosa. Using the polymerase chain reaction, however, it has recently been possible to show that there is a short viremic phase of $229 \mathrm{E}$, in at least some experimentally inoculated volunteers (S. Myint, unpublished data). The identification of the $229 \mathrm{E}$ receptor as a metalloprotease that is found on the surface of cells in many tissue types would also suggest a possible involvement of human coronaviruses in diseases other than just the common cold.

\section{PATHOGENESIS AND IMMUNE RESPONSE}

Little is known about the detailed pathogenic mechanisms in human coronavirus infection, principally because there is no animal model of infection. Even the predominant mode of transmission is uncertain. Infection can be induced experimentally by direct inoculation of virus into the nose, but this is unlikely to be the natural route. By analogy with rhinoviruses it is likely that infection is either by aerosols or fomites (Editorial, 1988). In support of this view is the finding that $229 \mathrm{E}$ survives well in an atmosphere of high humidity and low temperature (Ijaz et al., 1985).

Once in the nose, the virus is thought to enter the cell via a specific receptor, aminopeptidase $\mathrm{N}$. Replication is optimal at $32-33{ }^{\circ} \mathrm{C}$, the temperature in the superficial layers of the nasal mucosa. This results in sloughing of the superficial nasal epithelium and a proteinaceous exudate. Serum antibody levels rise after about a week, but it is not clear whether it is this response or cell-mediated mechanisms that clear the infection (Callow et al., 1990). Certainly, there is some correlation of the severity and likelihood of disease with preexisting serum antibody, but the mere presence of such antibody is not protective (Callow, 1985). Serum antibody levels peak about 2 weeks after infection and decline to low or undetectable levels at 12-18 months. Reinfections are common.

\section{DIAGNOSIS}

Because of the trivial and temporary nature of common colds, the detection of coronavirus infections has not been attempted in routine diagnostic laboratories. This situation is unlikely to change unless antiviral therapy becomes available. Although most techniques available to the diagnostic virologist have been used to detect human respiratory coronaviruses, even in research laboratories the range of tests employed by any one center tends to be limited. This chapter will give a synopsis of the range of methods used, but the reader is referred elsewhere for details of methods (Myint and Tyrrell, 1994).

\section{A. Organ Cultures}

The method, or modifications of it, developed by Tyrrell and Bynoe (1965) to isolate B814 is still used by some laboratories but is hampered by the diffi- 
culty of obtaining human embryonic tracheal tissue. It is the best method available for primary isolation of the broadest range of respiratory coronaviruses.

Tracheal tissue is taken from 14- to 24-week embryos and planted in sterile plastic Petri dishes containing 199 medium. The tissue is immersed with cilia uppermost. Virus can be inoculated onto the cilia and then incubated at $33^{\circ} \mathrm{C}$ for up to 10 days. Viral replication is indicated by cessation of ciliary activity and confirmed by interference with another virus (echovirus, parainfluenza, or Sendai). Electron microscopy was used originally to confirm the isolates as coronavirus but other tests such as virus neutralization are now employed.

Trachea obtained from 5- to 9-month-old fetuses have also been shown to support the growth of coronaviruses, and different media recipes can also be used (McIntosh et al., 1967a,b).

\section{B. Mouse Brain Culture}

OC38 and OC43 (but not B814, OC16, OC37, OC44, or OC48) have been adapted to grow in suckling mice brains (McIntosh et al., 1967a,b, 1970; Tyrrell et al., 1968b). The mice can be inoculated intracerebrally or via the peritoneum, with encephalitis occurring in some several days later. In the initial description of McIntosh and colleagues, CD-1 Swiss mice were used, with encephalitis occurring 11-15 days after inoculation with virus that had been passaged several times in organ culture. After the fourth passage, the time to illness was reduced to 40-60 hr. Evidence of infection was not found in other organs (e.g., liver, heart, or lungs). Virus can be prepared from brain suspensions by clarification through low-speed centrifugation and then adsorption to and elution from group $\mathrm{O}$ erythrocytes. Virus may be visualized by electron microscopy. Although this is not used for primary isolation of virus, this method is still a commonly used means of preparing OC43 antigen for serological assays.

\section{Cell Culture}

Cell cultures have proved to be unreliable for the primary isolation of all human respiratory coronaviruses, but certain strains have been adapted to growth in them. The 229E and related strains grow well in a continuous heteropoid cell line termed $\mathrm{Cl6}$, as they were the 16th clone of MRC-C cells that was selected (Philpotts, 1983). In the original description of these cells from the MRC Common Cold Unit in Salisbury, the morphology showed a mixture of fibroblastic and epithelioid cells. The former constituted three quarters of the cell population. These cells were contaminated with organisms detected by Hoechst stain 33258, presumably Mycoplasma spp. Thus, C16 cells would arguably be the cell line of choice for the isolation of $229 \mathrm{E}$, but frequent passage of these cells results in a increasing proportion of the epithelioid content and a consequent reduction in the ability of the cell line to sustain replication of virus. 
Many laboratories have continued to utilize a cell line that was originally used in the work of Hamre and Procknow (1966): a human diploid cell strain from Wistar Institute, so-called WI-38 cells. Although 229E was readily adapted to this cell line, primary isolation was in human kidney cells, and the authors noted that WI-38 cells may not be ideal for primary isolation.

Apart from C16 and Wi-38 cells, many other cell lines have been used to grow individual virus strains (Hamre and Procknow, 1966; Reed, 1984; Larson $e t$ al., 1980; Hamre et al., 1967; Kapikian et al., 1969; Bradburne, 1969, 1972; Schmidt et al., 1979; Schmidt and Kenny, 1982; Tyrrell et al., 1979; ChalonerLarsson and Johnson-Lussenberg, 1981; Bruckova et al., 1970). These are summarized in Table III. These viruses do not grow well in cell types commonly used for the isolation of other respiratory viruses such as HEp-2 or Rhesus monkey kidney, which makes routine identification unlikely. It is, moreover, clear that the ideal cell line for isolation and propagation is not yet available and other methods of diagnosis have to be applied.

\section{Electron Microscopy and Immune Electron Microscopy}

Electron microscopy of nasal washings is impractical as the virus load is usually below the level of sensitivity of standard methods. It has been used, however, to detect virus in tissue sections such as in mouse brain culture of OC43. It is also the means by which human enteric coronaviruses (HECVs) have been detected. Negative staining with tungsten has usually been the method of choice (Almeida and Tyrrell, 1967; Tyrrell and Bynoe, 1965), but molybdenum and uranium salts have also been used. The size of the particles appear greater if uranium salts are used in place of tungsten (Davies and MacNaughton, 1979).

TABLE III. Cell Lines and Strains Used for the Cultivation of Human Coronaviruses

\begin{tabular}{|c|c|c|}
\hline Cell type & Virus & Primary isolation or adaptation \\
\hline Human embryonic kidney & $229 \mathrm{E}$ & Primary \\
\hline $\mathrm{C} 16$ (see text) & $229 \mathrm{E}$ & Adaptation $\geqslant$ primary \\
\hline Human embryonic lung fibroblast, WI-38 & $229 \mathrm{E}$ & Adaptation $\geqslant$ primary \\
\hline Human embryonic lung fibroblast, MRC-c & $229 \mathrm{E}$ and OC43 & $\begin{array}{l}\text { Adaptation }>\text { primary } \\
(\mathrm{OC} 43, \text { adaptation only })\end{array}$ \\
\hline Human embryonic lung epithelium, L132 & $229 \mathrm{E}$ and OC43 & Adaptation $>$ primary \\
\hline $\begin{array}{l}\text { Human embryonic intestinal fibroblast, } \\
\text { MA177 }\end{array}$ & $229 \mathrm{E}$ & $\begin{array}{l}\text { Primary isolation of some } \\
\text { strains }\end{array}$ \\
\hline Human type II pneumocytes & $229 \mathrm{E}$ & Primary $>$ adaptation \\
\hline Human fetal tonsil fibroblast & $229 \mathrm{E}$ and $\mathrm{OC} 43$ & Adaptation \\
\hline Human embryonic rhabdomyosarcoma & $229 \mathrm{E}$ and $\mathrm{OC} 43$ & Adaptation \\
\hline Primary monkey kidney & $\mathrm{OC} 43$ & Adaptation \\
\hline $\begin{array}{l}\text { Rhesus monkey kidney epithelium, } \\
\text { LLC-MK2 }\end{array}$ & OC43 & Adaptation \\
\hline $\begin{array}{l}\text { Continuous green monkey kidney } \\
\text { epithelioid, BSC-1 }\end{array}$ & OC43 & Adaptation \\
\hline
\end{tabular}


An attempt to enhance electron microscopy by utilizing antibody concentration of cultured virus has been used successfully to detect 692 virus in washings from an adult with upper respiratory tract infection (Kapikian et al., 1973). Nasal washings were passaged through both cell culture and tracheal organ culture, and the resulting supernatant was then incubated with convalescent serum from the same patient. After centrifugation the pellet was then examined on a Formvar-carbon-coated grid. Aggregates of virus were clearly discernible. Supernatant that had been incubated with phosphate-buffered saline, instead of convalescent serum, was also examined but virus particles were not seen.

\section{E. Immunofluorescence}

An immunofluorescence method has been developed and applied to the detection of 229E and OC43 in nasopharyngeal secretions and washings (McIntosh et al., 1967a). Sera were raised in rabbits against mouse brain-derived OC43 and cell culture-grown 229E and used in an indirect fluorescence assay. This test was able to detect homologous coronavirus antigens in nasal washings from infected volunteers, though cross-reactivity was noted with the $229 \mathrm{E}$ antiserum in washings from volunteers who had been inoculated with OC43 and OC44. No nasopharyngeal aspirates from 106 children who were hospitalized with respiratory tract infection had detectable coronavirus antigen by this method. It is difficult to ascertain whether this was due to a lack of sensitivity, as paired sera collected from 66 children during the study period did not show evidence of coronavirus infection.

\section{F. Enzyme-Linked Immunoassay}

An enzyme-linked immunosorbent assay (ELISA) method based on purified 229E and HECV CV-Paris (which has cross-reactivity with OC43) has been used to diagnose infections in children (Isaacs et al., 1983; MacNaughton et al., 1983). The ELISA method is a modification of that described for antibody detection using rabbit antisera (see Section VI.I). In a study of 30 children aged 6 months to 6 years, 159 samples were collected: 111 nose swabs, 11 throat swabs, and 55 nasopharyngeal aspirates. Of these, $34.2 \%$ of the nose swabs, but only $18.2 \%$ of the throat swabs and nasopharyngeal aspirates, were positive for either $229 \mathrm{E}$ or OC43. No comparison with serology was attempted, but the positivity rate would suggest that this ELISA was a sensitive test.

\section{G. Nucleic Acid Hybridization}

The first application of gene detection methods to detecting human coronaviruses was developed for 229E using Northern hybridization (Myint et al., 1990). A cDNA that encoded the entire nucleocapsid gene for 229E was ligated 
into a Riboprobe (Promega) vector, pGEM-1, from which ${ }^{32}$ P-labeled full-length transcripts could be generated. These transcripts could be made as sense or antisense, depending on whether an SP6 or T7 promoter as used. This method has been applied to the detection of $229 \mathrm{E}$ in nasal washings from inoculated volunteers (Myint et al., 1989) and has been shown to be at least as sensitive as culture. There is also the advantage of a diagnostic result being available within $48 \mathrm{hr}$. An interesting observation was that the probe method was able to detect virus for longer than cell culture in sequential samples from the volunteers. This probe method will not detect $\mathrm{OC} 43$ and attempts to remove the radioactivelabeling by incorporating biotin or digoxigein into transcripts have led to significant loss of sensitivity (S. Myint, unpublished data).

\section{H. Reverse Transcription-Polymerase Chain Reaction}

With the advent of gene and probe amplification strategies, it was to be expected that these methods would be seen as advantageous for viruses that are difficult to cultivate. Gene amplification methods based on "nested" priming have been shown to be a sensitive and specific means of detecting both $229 \mathrm{E}$ and OC43 (Myint et al., 1994). Serotype-specific nested primers were designed from the known sequences of the nucleocapsid genes of 229E and OC43. The inner primers were, in particular, chosen to produce a small fragment of about 100 base pairs for maximum sensitivity. RNA is extracted using an acid-phenol/ guanidinium isothiocyanate procedure followed by reverse transcription using murine Moloney leukemia virus reverse transcription. Two 20-cycle amplification steps are then used with the outer and inner sets of primers, respectively. The sensitivity of the assay appears to be much greater than that of cell culture or probe methods and each primer pair appears to be either 229E or OC43 specific. The use of this method has greatly enhanced the diagnostic yield of coronaviruses in clinical material from asthmatic children (S. L. Johnston et al., unpublished data). The assay is, at least, as sensitive as a combination of culture and serology for diagnosing infection and is more specific. Reverse transcriptionpolymerase chain reaction is likely to become the method of choice for direct virus detection.

\section{Serological Methods}

Because of the lack of reliable detection methods prior to the development of those based on gene detection, most epidemiological studies have used serological assays to determine evidence of coronavirus infection. The most widely used and sensitive format is the enzyme-linked immunoassay. The assay was first described for strain 229E (Kraaijeveld et al., 1980; MacNaughton, 1982) but has since been adapted for detection of antibodies to OC43 (Schmidt, 1984). The $229 \mathrm{E}$ assay uses antigen that is grown in cell monolayers and then clarified. The OC43 test uses mouse-brain-derived antigen. Rabbit antisera have been used for both $229 \mathrm{E}$ and OC43 tests. The specificities of the assays are 
similar to that of counterimmunoelectrophoresis, neutralization, and complement fixation assays but sensitivity is over 1000 -fold greater. In volunteer studies, the $229 \mathrm{E}$ assay has shown a close correlation between clinical illness and virus shedding. It has been the principal method for determining the occurrence and frequency of coronaviruses infections in serological surveys, but recent data suggest that some false-positive and false-negative reactions occur (Myint et al., 1994). The 229E assay also detects antibody rises to some 229Elike viruses (PR, $\mathrm{KI}$, and $\mathrm{TO})$.

Other serological test formats have also been used: indirect hemagglutination (Kaye et al., 1972) and immune-adherence hemagglutination (Gerna et al., 1978) for 229E antibody; rapid microneutralization (Gerna et al., 1979) and plague-reduction (Gerna et al., 1980) for OC43 antibody; and immunofluorescence (Monto and Rhodes, 1977), complement fixation (Hovi, 1978), and single radial hemolysis (Hierholzer and Tannock, 1977; Riski et al., 1977) for both $229 \mathrm{E}$ and OC43 antibody. These test formats have been superseded by the ELISA test.

\section{REFERENCES}

Akerlund, A., 1993, Nasal pathophysiology in the common cold, PhD thesis, University of Lund, Sweden.

Almeida, J. D., and Tyrrell, D. A. J., 1967, The morphology of three previously uncharacterised human respiratory viruses that grow in organ culture, J. Gen. Virol. 1:175.

Andrewes, C. H., 1962, The Harben Lectures: The common cold, J. Roy. Inst. Public Health Hyg. (Suppl.).

Apostolov, K., and Spasic, P., 1975, Evidence of a viral aetiology in endemic (Balkan) nephropathy, Lancet 2:1271.

Arnold, W., Klein, M., Wang, J. B., Schmidt, W. A. K., and Trampisch, H. J., 1981, Coronavirusassociated antibodies in nasopharyngeal carcinoma and infectious mononucleosis, Arch. Otorhinolaryngol. 232:165.

Bende, M., Barrow, G. I., Heptonstall, J., Higgins, P. G., Al- Nakib, W., Tyrrell, D. A. J., and Akerlund, A., 1989, Changes in human nasal mucosa during experimental coronavirus commun colds, Acta Otolaryngol. 107:262.

Bradburne, A. F., 1969, Sensitivity of L 132 cells to some "new" respiratory viruses, Nature 221:85.

Bradburne, A. F., 1970, Antigenic relationships amongst coronaviruses, Arch. Ges. Virusforschung 31:352.

Bradburne, A. F., 1972, An investigation of the replication of coronaviruses in suspension cultures of L132 cells, Arch. Gesamte Virusforsch. 34:297.

Bradburne, A. F., Bynoe, M. L., and Tyrrell, D. A. J., 1967, Effects of a "new" human respiratory virus in volunteers, Br. Med. J. 3:767.

Bruckova, M., McIntosh, K., Kapikian, A. Z., and Chanock, R. M., 1970, The adaptation of two human coronavirus strains (OC38 and OC43) to growth in cell monolayers, Proc. Soc. Exp. Biol. Med. 135:431.

Burks, J. S., DeVald, B. L., Jankovsky, L. D., and Gerdes, J. C., 1980, Two coronaviruses isolated from central nerveous system tissue of two multiple sclerosis patients, Science 209:933.

Callow, K. A., 1985, Effect of specific humoral immunity and some non-specific factors on resistance of volunteers to respiratory coronavirus infection, J. Hyg. 95:173.

Callow, K. A., Parry, H. F., Sergeant, M., and Tyrrell, D. A. J., 1990, The time course of the immune response to experimental coronavirus infection of man, Epidemiol. Infect. 105:435.

Cavallaro, J. J., and Monto, A. S., 1970, Community-wide outbreak of infection with a 229E-like coronavirus in Tecumseh, Michigan, I. Infect. Dis. 122:272. 
Chaloner-Larsson, G., and Johnson-Lussenberg, C. M., 1981, Establishment and maintenance of a persistent infection of L132 cells by human coronavirus strain 229E, Arch. Virol. 69:117.

Davies, H. A., and MacNaughton, M. R., 1979, Comparison of the morphology of three coronaviruses, Arch. Virol. 59:25.

Editorial, 1988, Splints don't stop colds-surprising! Lancet 1:277.

Fleming, J. O., El Zaatari, F. A. K., Gilmore, W., Berne, J. D., Burks, J. S., Stohlman, S. A., Tourtellote, W. W., and Weiner, L. P., 1988, Antigenic assessment of coronaviruses isolated from patients with multiple sclerosis, Arch. Neurol. 45:629.

Gerdes, J. C., Klein, I., DeVald, B. L., and Burks, J. S., 1981, Coronavirus isolates SK and SD from multiple sclerosis patients are serologically related to murine coronaviruses A59 and JHM and human coronavirus OC43, but not to human coronavirus 229E, J. Virol. 38:231.

Gerna, G., Achilli, G., Cattaneo, E., and Cereda, P., 1978, Determination of coronavirus 229E antibody by an immune-adherence haemagglutination method, $J$. Med. Virol. 2:215.

Gerna, G., Cereda, P. M., Revello, M. G., Torsellini Gerna, M., and Costa, J., 1979, A rapid microneutralisation test for antibody determination and serodiagnosis of human coronavirus OC 43 infections, Microbiologica 2:331.

Gerna, G., Cattaneo, E., Cereda, P. M., Revelo, M. G., and Achilli, G., 1980, Human coronavirus serum inhibitor and neutralizing antibody by a new plaque-reduction assay, Proc. Soc. Exp. Biol. Med. 163:360.

Hamre, D., and Beem, M., 1972, Virologic studies of acute respiratory disease in young adults. V. Coronavirus 229E infections during six years of surveillance, Am. J. Epidemiol. 96:94.

Hamre, D., and Procknow, J. J., 1966, A new virus isolated from the human respiratory tract, Proc. Soc. Exp. Biol. 121:190.

Hamre, D., Kindig, D. A., and Mann, J., 1967, Growth and intracellular development of a new respiratory virus, $J$. Virol. 1:810.

Hierholzer, J. C., and Tannock, G. A., 1977, Quantitation of antibody to nonhaemagglutinating viruses by single radial haemolysis: Serological test for human coronaviruses, J. Clin. Microbiol. 5:613.

Hovanec, D. L., and Flanagan, T. D., 1933, Detection of antibodies to human coronaviruses 229E and OC43 in the sera of multiple sclerosis patients and normal subjects, Infect. Immun. 41:426.

Hovi, T., 1978,Nonspecific inhibitors of coronavirus OC43 haemagglutination in human sera, Med. Microbiol. Immunol. 166:1773.

Ijaz, M. K., Brunner, A. H., Sattar, S. A., Nair, R. C., and Johnson-Lussenberg, C. M., 1985, Survival characteristics of airborne human coronavirus 229E, J. Gen. Virol. 66:2743.

Isaacs, D., Flowers, D., Clarke, J. R., Valman, H. B., and MacNaughton, M. R., 1983, Epdemiology of coronavirus respiratory infections, Arch. Dis. Child. 58:500.

Kapikian, A. Z., James, H. D., Kelly, S. J., Dees, J. H., Turner, H. C., Mcintosh, K., Kim, H. W., Parrott, R. H., Vincent, M. M., and Chanock, R., 1969, Isolation from man of "avian infectious bronchitis virus-like" viruses (coronaviruses) similiar to $229 \mathrm{E}$ virus with some epidemiological observations, I. Infect. Dis. 119:282.

Kapikian, A. Z., James, H. D., Kelly, S. J., and Vaughn, A. L., 1973, Detection of coronavirus strain 692 by immune electron microscopy, Infect. Immun. 7:111.

Kaye, H. S., Marsh, H. B., and Dowdle, W. R., 1971, Seroepidemiologic survey of coronavirus (strain OC43) related infections in a children population, Am. J. Epidemiol. 94:43.

Kaye, H. S., Ong, S. B., and Dowdle, W. R., 1972, Detection of coronavirus 229E antibody by indirect haemagglutination, Appl. Microbiol. 24:703.

Kraaijeveld, C. A., Reed, S. E., and MacNaughton, M. R., 1980, Enzyme-linked immunosorbent assay for detection of antibody in volunteers experimentally infected with human coronavirus strain 229E, J. Clin. Microbiol. 12:493.

Larson, H. E., Reed, S. E., and Tyrrell, D. A. J., 1980, Isolation of rhinoviruses and coronaviruses from 38 colds in adults, J. Med. Virol. 5:221.

Leinikki, P. O., Holmes, K. V., Shekarchi, I., Iivainen, M., Madden, D., Sever, J. L., 1981, Coronavirus antibodies in patients with multiple sclerosis, $A d v$. Exp. Med. Biol. 142:323.

Lowenstein, S. R., and Parrino, T. A., 1987, Management of the common cold, Adv. Intern. Med. 32:207. 
MacNaughton, M. R., 1982, Occurrence and frequency of coronavirus infections in humans as determined by enzyme-linked immunosorbent assay, Infect. Immun. 38:419.

MacNaughton, M. R., Flowers, D., and Isaacs, D., 1983, Diagnosis of human coronavirus infections in children using enzyme-linked immunosorbent assay, J. Med. Virol. 11:319.

Madden, D. L., Wallen, W. C., Houff, S. A., Leinikki, P. A., Sever, J. L., Holmes, K. A., Castellano, G. A., and Shekarchi, I. C., 1981, Coronavirus antibodies in sera from patients with multiple sclerosis and matched controls, Arch. Neurol. 38:209.

McIntosh, K., Dees, J. H., Becker, W. B., Kapikian, A. Z., and Chanock, R. M., 1967a, Recovery in tracheal organ cultures of novel viruses from patients with respiratory disease, Proc. Natl. Acad. Sci. USA 57:933.

McIntosh, K., Becker, W. B., and Chanock, R. M., 1967b, Growth in suckling mice brain of IBV-like viruses from patients with upper respiratory tract disease, Proc. Natl. Acad. Sci. USA 58:2268.

McIntosh, K., Kapikian, A. Z., Hardison, K. A., Hartley, J. W., and Chanock, R. M., 1969, Antigenic relationships among the coronaviruses of man and between human and animal coronaviruses, J. Immunol. 102:1109.

McIntosh, K., Bruckova, M., Kapikian, A. Z., Chanock, R., and Turner, H., 1970a, Studies on new virus isolates recovered in tracheal organ culture, Ann. NY Acad. Sci., 174:983.

McIntosh, K., Kapikian, A. Z., Turner, H. C., Hartley, J. W., Parrott, R. H., and Chanock, R. M., 1970b, Seroepidemiologic studies of coronavirus infection in adults and children, Am. J. Epidemiol. 91:585.

McIntosh, K., Ellis, E. F., Hoffmann, L. S., Lybass, T. G., Eller, J. J., and Fulginiti, V. A., 1973, The association of viral and bacterial respiratory infections with exacerbations of wheezing in young asthmatic children, J. Paediatr. 82:579.

McIntosh, K., Chao, R. K., Krause, H. E., Wasil, R., Mocega, H. E., and Mufson, M. A., 1974, Coronavirus infections in lower respiratory tract disease of infants, $J$. Infect. Dis. 130:502.

Monto, A. S., and Lim, S. K., 1974, The Tecumseh study of respiratory illness. VI. Frequency of and relationship between outbreaks of coronavirus infection, $J$. Infect. Dis. 129:271.

Monto, A. S., and Rhodes, L. M., 1977, Detection of coronavirus infection of man by immunofluorescence, Proc. Soc. Exp. Biol. Med. 155:143.

Myint, S., and Tyrrell, D. A. J., 1994, Coronaviruses, in: Diagnostic Procedures for Viral, Rickettsial and Chlamydial Infections (E. H. Lenette, E. T. Lennette, and D. A. Lennette, eds.), pp. 709723. American Public Health Association, Berkeley, CA.

Myint, S., Siddell, S., and Tyrrell, D., 1989, Detection of human coronavirus 229E in nasal washings using RNA:RNA hybridisation, J. Med. Virol. 29:70.

Myint, S., Harmsen, D., Raabe, T., and Siddell, S. G., 1990, Characterisation of a nucleic acid probe for the diagnosis of human coronavirus 229E infections, J. Med. Virol. 31:165.

Myint, S., Johnstone, S., Sanderson, G., and Simpson, H., 1994, The evaluation of "nested" RT-PCR for the detection of human coronaviruses $229 \mathrm{E}$ and OC43 in clinical specimens, Mol. Cell. Probes. 8:357.

Owen-Hendley, J. O., Fishburne, H. B., and Gwaltney, J. M., 1972, Coronavirus infections in working adults, Am. Rev. Resp. Dis. 105:805.

Philpotts, R., 1983, Clones of MRC-c cells may be superior to the parent line for the culture of 229Elike strains of human respiratory coronavirus, I. Virol. Methods 6:267.

Reed, S. E., 1984, The behaviour of recent isolates of human respiratory coronavirus in vitro and in volunteers: Evidence of heterogeneity among 229E-related strains, $J$. Med. Virol. 13:179.

Riski, H., and Hovi, T., 1980, Coronavirus infections of man associated with diseases other than the common cold, J. Med. Virol. 6:259.

Riski, H., Hovi, T., Vaananen, P., and Penttinen, K., 1977, Antibodies to human coronavirus OC 43 measured by radial haemolysis in gel, Scand. I. Infect. Dis. 9:75.

Salmi, A., Ziola, B., Hovi, T., and Reunanen, M., 1982, Antibodies to coronaviruses OC43 and 229E in multiple sclerosis patients, Neurology 32:292.

Schmidt, O. W., 1984, Antigenic characterisation of human coronaviruses $229 \mathrm{E}$ and OC43 by enzyme-linked immunosorbent assay, J. Clin. Microbiol. 20:175.

Schmidt, O. W., and Kenny, G. E., 1982, Polypeptides and functions of antigens from human coronaviruses 229E and OC 43, Infect. Immun. 35:515.

Schmidt, O. W., Cooney, M. K., and Kenny, G. E., 1979, Plaque assay and improved yield of human 
coronaviruses $229 \mathrm{E}$ and OC43 in a human rhabdomyosarcoma cell line, $J$. Clin. Microbiol. 9:722.

Sorensen, O., Collins, A., Flintoff, W., Ebers, G., and Dales, S., 1986, Probing for the human coronavirus OC43 in multiple sclerosis, Neurology 35:1604.

Stewart, J. N., Mounir, S., and Talbot, P. J., 1992, Human coronavirus gene expression in the brains of multiple sclerosis patients, Virology 191:502.

Tanaka, R., Iwasaki, Y., and Koprowski, H., 1976, Intracisternal virus-like particles in brain of a multiple sclerosis patient, I. Neurol. Sci. 28:121.

Tyrrell, D. A. J., and Bynoe, M. L., 1965, Cultivation of a novel type of common cold virus in organ culture, Br. Med. J. 1:1467.

Tyrrell, D. A. J., Almeida, J. D., Berry, D. M., Cunningham, C. H., Hamre, D., Hofstad, M. S., Malluci, L., and McIntosh, K., 1968a, Coronaviruses, Nature 220:650.

Tyrrell, D. A. J., Bynoe, M. L., and Hoorn, B., 1968b, Cultivation of "difficult" viruses from patients with common colds, Br. Med. J. 1:606.

Tyrrell, D. A. J., Mika-Johnson, M., Philips, G., Douglas, W. H. J., Chapple, P. J., 1979, Infection of cultured human type II pneumocytes with certain respiratory viruses, Infect. Immun. 26:621.

Tyrrell, D. A. J., Cohen, S., and Schlarb, J. E., 1993, Signs and symptoms in common colds, Epidemiol. Infect. 111:143.

Weiss, S. R., 1983, Coronaviruses SD and SK share extensive nucleotide homology with murine coronavirus MHV-A59, more than that shared between human and murine coronaviruses, Virology 126:669.

Wenzel, R. P., Hendley, J. O., Davies, J. A., and Gwaltney, J. M., 1974, Coronavirus infections in military recruits, Annu. Rev. Resp. Dis. 109:621. 